\title{
Long-term discriminated avoidance in two species of fish
}

KENNETH B. MELVIN AND FRANK H. SMITH

UNIVERSITY OF ALABAMA
Three bass and two sunfish leamed a discriminated avoidance response in a shuttle box. During 3300 further trials, all $S$ s showed excellent performance with no decrement, a minimal "warm-up" effect, and stereotyped response topography.

The vast literature pertaining to discriminated avoidance in rats consists mainly of short-term studies. In certain instances, extended training resulted in a loss of avoidance behavior (e.g., Anderson \& Nakamura, 1964; Anderson, Rollins, \& Riskin, 1966). This "avoidance decrement" typically occurred with the use of a wheel turning response. Two studies of shuttle responding, however, reported no avoidance decrement over 2160 trials (Badia \& Levine, 1964) or 640-840 trials (Weisman, Zerbolio, \& Denny, 1965).

Although discriminated avoidance behavior has been established in several species of fish (e.g., Wodinsky, Behrend \& Bitterman, 1962; Pinckney, 1966; Werboff \& Lloyd, 1963), it has not been studied over an extended series of trials. Typically only 100-200 training trials were administered at the rate of 10-20 per day. The present study attempted to determine if (a) largemouth bass and bluegill sunfish could learn a shuttle-avoidance response and (b) such a response could be maintained over 3300 trials.

Subjects

The Ss were five largemouth bass (Micropterus salmoides) 10-12 in. long and two bluegill sunfish (Lepomis machrochirus) 5-7 in. long. The fish were obtained by the Es from a local lake, kept in the laboratory in 15 gallon aquaria, and fed on minnows and earthworms.

\section{Apparafus}

The major portion of the apparatus was a 15 gallon aquarium enclosed in a box. A 4 in. high perforated aluminum hurdle divided the box into two compartments 12 in. wide and 12 in. long; the water level was 3 to 5 in. above the hurdle, depending on the size of the fish. A mesh floor 2 in. from the bottom of the aquarium reduced the effective height of the hurdle to $2 \mathrm{in}$. A photobeam was situated 1.5 in. above this hurdle. Aluminum screens at each end of the tank served as electrodes. All stimulus presentation and timing was programmed by standard relay equipment and timers. Counters and an event recorder served to record intertrial, escape, and avoidance responses.

\section{Procedure}

On Day 1, $\mathrm{S}$ was placed in the shuttle box and given $10 \mathrm{~min}$. of adaptation and then five trials with just the CS, which consisted of 10 sec. of illumination provided by lights at both ends of the tank (no $S$ escaped from the CS). All trials were given at a $1 \mathrm{~min}$. intertrial interval. On Day 1, Ss were given 20 training trials. If $\mathbf{S}$ broke the photobeam and then moved out of it during the $10 \mathrm{sec}$. CS-US interval, the CS was terminated and the US prevented. If no avoidance or escape response was made, the US terminated automatically after 15 sec., an event which shut off the CS. The US was a pulsating shock of $6-8 \mathrm{~V}$ ac.

On Day 2 Ss were given 40 trials; on Day 3,80 trials. Fish which were avoiding $80 \%$ on the last 20 trials of Day 3 were given 11 sessions of 300 trials per day. One bass was then given a rest interval of 10 days, four days of "retraining" (300 trials per day), one day of extinction, followed by a 300-trial day of relearning, and a final 1000-trial session. Another bass and two sunfish were given a 600-trial extinction session, which was identical to the training session except for the omission of the US.

\section{Results and Discussion}

Three of five bass learned the avoidance task to a criterion of $80 \%$ on Day 3 of acquisition-a failure rate not unlike that of the rat in the two-way avoidance situation (Bindra, 1961). Table 1 presents the percentage of avoidance responses over part or all of the 3300 trials. Obviously, there was no "avoidance decrement"-these fish maintained their excellent avoidance performance throughout the experiment. One S showed no loss of response after a 10-day rest. This fish also exhibited extinction, rapid relearning and finally stable performance (99\% avoidance) over a 1000 trial, $16.6 \mathrm{hr}$. session.

The intertrial responses were few during the first 300-trial day, but increased during the next three sessions. By the last two sessions, however, intertrial responses were negligible in frequency. Observation revealed that, while the fish avoided successfully over the 3300 trials, the efficiency of behavior improved during trials 900-2700. During this phase, Ss

Table 1. Percentage of Conditioned Avoidance Responses for Each Bass (300 Trials per Session).

\begin{tabular}{lccc} 
& \multicolumn{3}{c}{ Ss } \\
& B1 & B2 & B5 \\
\hline Median (11 Sessions) & 95.3 & 97.3 & 97.3 \\
Range (11 Sessions) & $89.7-99.7$ & $87.7-100.0$ & $85.3-99.7$ \\
Median (session 1-3) & 88.7 & 96.0 & 96.0 \\
Median (Sessions 9-11) & 99.0 & 96.3 & 99.3 \\
Median (Session 12-Retention) & --- & 98.3 & --- \\
\hline
\end{tabular}


adopted one of two stereotyped responses: (a) swimming through the photobeam, and then turning and facing it or (b) moving forward until the beam was broken, then backing into the original position. As one of these responses became thoroughly established, intertrial responses were greatly reduced.

Simflar results were obtained with another species also belonging to the family Centrarchidae, i.e.,bluegll sunfish. Under similar conditions, two sunfish showed no avoidance decrement over 3300 trials. ${ }^{1}$ Both Ss maintained a $99 \%$ avoidance level over the last 1500 trials, and both Ss extinguished with the omission of the US. It should be noted that extinction was rapid (if one assumes that this procedure begins the first time that $S$ does not respond during the 10 sec. CS-US interval and recelves no shock).

Both species showed a minimal "warm up" effect. Typically, the first shock was received early in the sesston, and any further shocks were evenly distributed over the remainder of the session.

These data demonstrate that bass and sunfish learned a shuttle avoidance response. Furthermore, this response was maintained at a high and stable level over many trials. These results, in conjunction with those of Badia \& Levine (1964), tend to indicate that the avoidance decrement is specific to the interaction of a certain type of response with a particular species.

\section{References}

Anderson, N. H., \& Nakamura, C. Y. Avoidance decrement in avoidance conditioning. J. comp. physiol. Psychol., 1964, 57, 196-204.

Anderson, N. H., Rollins, H. A., \& Riskin, S. R. Effects of punishment on avoidance decrement. J. comp. physiol. Psychol., $1966,62,147-149$.

Badia, P., \& Levine, S. Stable Iong term avoidance responding and fixed ratio avoidance trainipg. Psychon. Sci., 1964, 1, 91-92.

Bindra, D. Components of general activity and the analysis of behavior. Psychol. Rev., 1961, 68, 205-215.

Pinckpey, G. A. The effect of intertrial interval on avoidance learning in fish. Psychon. Sci., 1966, 6, 479-498.

Weisman, R. G., Zerbolio, D. J., \& Denny, M. R. Intertrial interval in the maintenance of discrete-trial avoidance. Psychon. Sci., $1965,2,33-34$.

Werboff, J., \& Lloyd, T. Avoidance conditioning in the guppy (Lebistes reticulatus). Psychol. Rep., 1963, 12, 615-618.

Wodinsky, J., Behrend, E. R., \& Bitterman, M. E. Avoidance-conditioning in two species of fish. Anim. Behav., 1962, 10, 76-78. Note

1. One sunfish avoided shock for 1403 consecutive trials, a feat apparently unrivaled in the annals of piscatorical avoidance. 